\title{
A UNIVERSITY QUALITY ASSURANCE TEAM SHOULD STRIVE FOR QUALITY OF WORK-LIFE
}

\author{
Dzikrina Syahidah*, Siti Zulaikha, Masduki Ahmad \\ Jakarta State University, Indonesia \\ *e-mail: syahidah.dzikrina@gmail.com
}

\begin{abstract}
Professionalism is an important key to an organization in achieving their success. One of the essential factors influencing the formation of committed professional resources is the employees' perception of the quality of their work life. This study aims to examine the effects of the quality of work life (QWL) (appropriate and fair compensation, work stress, employee participation, career growth and development, social relevance, work environment) on organizational commitment (OC) simultaneously or partially. The participants of this study were 109 quality assurance team employees at a state university in Indonesia. The data collected through questionnaires were analyzed by simple regression and Pearson's correlation test. The results showed that there is a significant influence between QWL and OC. The six predictors of QWL showed a significant relationship with OC $(r<.05)$ with the most influencing indicators as follows: career growth and development $(p=.612)$, appropriate and fair compensation $(p=.558)$, employee participation $(p=.515)$, work stress $(p=-.510)$, social relevance $(p=.498)$, and work environment $(p=$ .422). This study suggests that a state university shoud provide wider opportunities for quality assurance employees to develop and demonstrate their abilities and creativity as an effort to increase their OC.
\end{abstract}

Keywords: higher education, organizational commitment, quality assurance team, quality of work life.

\section{TIM PENJAMINAN MUTU UNIVERSITAS HARUS MENDORONG KUALITAS KEHIDUPAN KERJA}

\begin{abstract}
Abstrak: Profesionalisme menjadi kunci penting suatu organisasi dalam mencapai kesuksesannya. Salah satu faktor esensial yang memengaruhi terbentuknya sumber daya profesional berkomitmen tersebut adalah persepsi para pegawai terhadap kualitas kehidupan kerjanya. Penelitian ini bertujuan untuk menganalisis pengaruh kualitas kehidupan kerja (kompensasi yang sesuai dan adil, stres kerja, partisipasi karyawan, pertumbuhan dan pengembangan karir, relevansi sosial, dan lingkungan kerja) terhadap komitmen organisasi secara simultan maupun secara parsial. Sebanyak 109 karyawan yang bekerja sebagai tim penjaminan mutu di sebuah universitas negeri di Indonesia dilibatkan dalam penelitian ini. Data yang dikumpulkan melalui kuesioner dianalisis dengan tes regresi sederhana dan korelasi Pearson. Hasil penelitian menunjukkan adanya pengaruh signifikan antara kualitas kehidupan kerja dengan komitmen organisasi. Selain itu, keenam prediktor QWL memperlihatkan adanya hubungan signifikan dengan komitmen organisasi $(r<.05)$ dengan indikator yang paling mempengaruhinya adalah: pertumbuhan dan perkembangan karir $(p=.612)$, kompensasi yang sesuai dan adil $(p=.558)$, partisipasi karyawan $(p=.515)$, stres kerja $(p=-.510)$, relevansi sosial $(p=.498)$, dan lingkungan kerja $(p=.422)$. Studi ini kemudian merekomendasikan bahwa suatu universitas negeri sebaiknya memberikan kesempatan yang lebih luas kepada para pegawai penjaminan mutu untuk berkembang dan menunjukkan kemampuan serta kreativitasnya sebagai upaya dalam meningkatkan komitmen organisasi mereka.
\end{abstract}

Kata Kunci: pendidikan tinggi, komitmen kerja, tim penjaminan mutu, kualitas kehidupan kerja.

\section{INTRODUCTION}

Education is an effort carried out systematically to transform knowledge and social values, the formation of character and personality, and teach skills and creativity. While in the broadest sense, education has meaning as a process related to efforts in developing three aspects of life in a person: life outlook, life attitude, and life skill.

A college is an educational unit that organizes higher education which includes education programs of academic, vocational, 
and/or professional (Darmadi, 2019). The process of globalization, free-market activities, the high needs of the community, and increasingly intense competition, especially in this Industrial Era 4.0 , became a formidable challenge for college organizers. This condition appears because colleges are not only seen as centers of science, research, and community service, but also as "science-producing" a corporate entity that needs to "compete" to ensure survival (Syukron, 2017).

In addition to considering price and service factors, monitoring related to quality becomes one of the strategies that must always be well planned and implemented optimally in order to face the challenges of education in the development of various industries in this era. In this case, improving the quality of education in colleges can be done by making improvements, changes, and updates on the factors influencing the success of education, namely the institutional subsystem relating to humans, structure, technology, and organizational processes.

Human resources play an essential role in determining the progress of an organization or even a country (Jabbour \& Santos, 2008; Tabassum, 2020). Suppose an organization has abundant non-human resources (like natural resources, capital, markets, information, and other resources), but quality human resources don't support it, then the organization will tend to be difficult or slow to develop because they cannot manage their resources properly. Therefore, the existence of quality human resources is a central factor in an organization whose management is also a determining factor of the progress or stagnation of activities in the institution.

Quality of Education in higher education will be more assured if it has a good and robust Quality Assurance System of Higher Education with its leaders and organizational members able to integrate the organization's vision, mission, and goals into their vision, mission, and goals (Kardoyo, 2011). Thus the harmony of the quality culture of individual leaders and organizational actors will be formed. Based on previous and theoretical studies related to organizational behavior, it is known that many factors can determine a person's success in their field of work, such us organizational commitment (Geisler, Berthelsen, \& Muhonen,
2019; Holsblat, 2014), professionalism (Jie, Mansor, \& Kelana, 2020a, 2020b), and level of competence in the area they occupy (Kartika \& Sugiarto, 2016; Supriyadi \& Sarino, 2019).

Organizational commitment (OC) is often defined as a person's loyalty to his organization. Meyer \& Herscovitch (2001) argue that OC is a force that binds an individual to a course of action of relevance to a target. OC can also be defined as an employee's effort to get to know the organization and try to work in line with its objectives and has a desire to maintain its membership (Robbins \& Judge, 2013). In general, this OC will show the individual's attitude towards the organization where he works (Greenberg, 2010). Hence, OC can be defined as one of the responses of the psychological conditions felt by employees of their organization as indicated by the form of attitude, contribution/ involvement, and loyalty to the organization.

It is known that there are at least two fundamental reasons that are expressed by experts to explain why the discussion about commitment becomes essential and interesting to study when discussing organizational behavior. First, it is basically not enough for organizations to only have talented employees who perform their jobs well, but organizations also need be able to hang on to those employees for long periods so that the organization can benefit from their efforts (Colquitt, Lepine, \& Wesson, 2015; Daud, 2010). Second, there have been many studies that show that commitment can predict work outcomes, such as the intention of individuals to leave work, performance in the organization, absence, and tardiness (Cohen, 2011; Colquitt et al., 2015; Robbins \& Judge, 2013; Tnay, Othman, Siong, \& Lim, 2013). Besides, based on the results Ghoniyah \& Masurip's (2011) research, it is known that levels of commitment basically can describe the level of optimization of employee performance, which will then affect the effectiveness and efficiency of the organization in achieving its goals. In general, it can be recognized that employee commitment to the organization is one essential factor that influences the success and failure of an organization. It is true if it is not an easy and simple matter in growing high OC to employees in an organization, but by taking corrective actions or developing factors that can affect commitment itself can be an effective way 
of increasing it.

Quality of work life (QWL) is one of the factors that influence employee commitment to his organization. QWL has emerged as a managerial strategy aimed at creating an enabling environment for employees to maximize their potential (Osibanjo, Oyewunmi, Abiodun, \& Oyewunmi, 2019). The term QWL can be understood as providing employee needs to ensure the physical and mental well-being of employees, so that their loyalty, contribution, and enthusiasm in doing their work increases (Gibson, Ivancevich, Donnelly, \& Konopaske, 2012; Hasmalawati \& Hasanati, 2017; Tanriverdi, Turan, \& Yilmaz, 2019). The needs provided can be in the form of a safe work environment, a fair reward system, healthy communication that is built between employees, providing appropriate and broad opportunities for career and development, and giving employees the opportunity to be involved in decision making (Hasmalawati \& Hasanati, 2017; Rogelberg, 2007; Tanriverdi et al., 2019).

Basically, the concept and application of QWL are not just about jobs, but also about the source of satisfaction that is felt important by the employees who do the jobs (Gibson et al., 2012). Referring to the opinion of Greenberg (2010) and Rogelberg (2007), the conditions mentioned earlier can be realized by striving to fulfil work balance that is considered necessary for employees, such as giving fair and supportive treatment, giving opportunities for every employee to use their abilities fully, and provide opportunities to play an active role in making important decisions that involve their work.

Robbins \& Judge (2013) argue that an organization that does not help its employees achieve balance in work life will find it increasingly difficult to attract and retain their best employees. That is because organizations that continually strive to help balance the personal lives of employees with their work, basically they are also making efforts on reducing employee stress levels, increasing employee job satisfaction, and increasing the effectiveness of their organizations. With the creation of this positive work environment, the level of employee loyalty to their organizations will indirectly increase. Conversely, when the level of QWL in an organization turns out to be low (e.g. employee coaching systems that are not optimal and do not touch their basic needs, or lack of organizational attention to employee welfare), then the possibility of the organization to get employees' commitment, loyalty, or high performance will be low too (Beloor, Nanjundeswaraswamy, \& Swamy, 2017; Daud, 2010; Ghoniyah \& Masurip, 2011; Tamhir, Sujanto, \& Karnati, 2019).

Based on the description above and considering that work and job are essential issues of human life, which if it is in accordance with the conditions and favorites, will have the desired effect on individuals and society. Therefore, it is necessary to do more comprehensive research related to employee quality of work life because it has an impact not only on the effectiveness and efficiency of achieving organizational goals but also on the mental health problems of employees and the organization. From the research results conducted later, managers can identify important and key factors affecting improving working environment by measuring this quality of working life.

This study has main purpose that is to analyze the effect of QWL on employee OC of quality assurance of education at a state university. In addition, an analysis of six determinant factors or predictors of QWL variables (appropriate and fair compensation, employee participation, career growth and development, social relevance, work environment, and work stress) that affect OC is also carried out. The results are expected to be recommendations in fulfilling the QWL of employees of the quality assurance team of a state university as a means of increasing the OC.

\section{METHODS}

This research uses a quantitative approach with survey methods. Data collection is carried out through a questionnaire given to all employees who are members of the education quality assurance teams in each faculty of a state university, in Jakarta, Indonesia. The total number of respondents was one hundred and nine (109) employees who spread across nine (9) faculties and ninety-three (93) majors. In this study, quality of work life plays a role as the independent variable of research, and organizational commitment as the dependent variable.

The five-level Likert scale was used ranging from $1=$ 'strongly disagree' to $5=$ 
'strongly agree' was used to measure the variables in this study. Before testing data analysis, it is necessary to test the analysis requirements to prove that the questionnaire is suitable for use as a research instrument and data is normally distributed. To find out, it is confirmed by the validity test, reliability test, normality test, and linearity test.

This research content validity applied expert judgment involving 21 experts and with a signification point .01 . Formula to measure the content validity coefficient of the research was using a formula proposed by Aiken, which was later known by Aiken's $V$. The researchers set the probability of error at $p_{\text {value }}$ is $1 \%$, so the minimum value of $V$ based on the index of table $V$ with five categories is .69. Cronbach's alpha reliability test was used to determine the level of consistency of the questionnaire used in this study. A survey can be declared to be reliable, or the questionnaire is feasible to be used as a research instrument if the variable has Cronbach's alpha coefficient value greater than .60. The results and decision of this study's validity and reliability tests can be seen in Table 1 and Table 2.
After testing the analysis requirements have been met, the data obtained were analyzed first using descriptive statistical analysis and then completed by path analysis consisting of the hypothesis test and decision of effect level. Research hypotheses to determine whether there is an influence between the independent variable (QWL) and the dependent variable (OC) was analyzed using simple regression test. While analysis to determine the relationship between six of QWL predictor (appropriate and fair compensation, employee participation, career growth and development, social relevance, work environment, work stress) on $\mathrm{OC}$ of the quality assurance team's of a state university was carried out using Pearson's Correlation Coefficient at the .05 significance level.

The strength of the relationship between the six indicators of QWL on OC of a state university quality assurance team is categorized based on Cohen's empirical classification, which interprets the strength of the correlation using $r$. Overall, data analysis was performed using the Statistical Package for Social Science (SPSS) application for Windows.

Table 1. Result of Questionnaire Validity

\begin{tabular}{llccc}
\hline Variable & Blueprint & $\begin{array}{c}\text { Total Number of } \\
\text { Items }\end{array}$ & $\begin{array}{c}\text { Aiken's } \boldsymbol{V} \\
\text { Value }\end{array}$ & Decision \\
\hline \multirow{5}{*}{$\begin{array}{l}\text { Quality of Work } \\
\text { Life }\end{array}$} & Appropriate and fair compensation & 5 & .7357 & Valid \\
& Employee participation & 5 & .8095 & Valid \\
& Career growth and development & 5 & .8143 & Valid \\
& Social relevance & 7 & .8316 & Valid \\
& Work environment & 6 & .8016 & Valid \\
& Work stress & 6 & .7937 & Valid \\
& & $\mathbf{3 4}$ & & \\
\hline \multirow{3}{*}{$\begin{array}{l}\text { Organizational } \\
\text { Commitment }\end{array}$} & Acceptance of organizational goals & 8 & .8289 & Valid \\
& Involvement in interpersonal behavior & 5 & .7810 & Valid \\
& within organizations & 8 & .8065 & Valid \\
& Accountable dedication & 6 & .7679 & Valid \\
& Sincerity in doing tasks to achieve & 7 & .7041 & Valid \\
& what is expected & & & \\
\hline
\end{tabular}

Table 2. Result of Questionnaire Reliability

\begin{tabular}{lcl}
\hline Variable & Cronbach's Alpha Coefficient Value & Decision \\
\hline Quality of Work Life $(\mathrm{QWL})$ & .933 & Reliable \\
Organizational Commitment $(\mathrm{OC})$ & .877 & Reliable \\
\hline
\end{tabular}




\section{FINDINGS AND DISCUSSION Findings \\ Test of Descriptive Statistics}

Data on quality of work life (QWL) and organizational commitment (OC) variables are presented in the form of descriptive statistics. Descriptive statistics are used to describe the basic features of the data in the study and provide simple summaries about the sample and the measures. The descriptive statistical data is presented in Table 3.

\section{Normality Test}

The Kolmogorov-Smirnov normality test is performed to find out that the data is normally distributed as a requirement for the classical assumption test. The normality test shows the significance residual value of OC data is .412 $(p>.05)$, so it can be said the data is normally distributed. Kolmogorov-Smirnov value also shows that the assumption of normality had been fulfilled. The summary of the result of the normality test is shown in Table 4.

Table 3. Summary of Descriptive Statistics

\begin{tabular}{lccccccc}
\hline \multirow{2}{*}{ Variable } & \multicolumn{7}{c}{ Description } \\
\cline { 2 - 8 } & $\boldsymbol{n}$ & Range & Min & Max & Mean & Std. Deviation & Variance \\
\hline Organizational Commitment & 109 & 65.00 & 102.00 & 167.00 & 136.404 & 11.542 & 133.224 \\
Quality of Work Life & 109 & 90.00 & 80.00 & 170.00 & 133.936 & 13.722 & 188.283 \\
\hline
\end{tabular}

Table 4. Summary of Normality Test

\begin{tabular}{lcccl}
\hline $\begin{array}{l}\text { Estimation Error of } \\
\text { Regression }\end{array}$ & $\boldsymbol{n}$ & $\begin{array}{c}\text { Kolmogorov- } \\
\text { Smirnov Z }\end{array}$ & $\begin{array}{c}\text { Asymp. Sig. } \\
\text { (2-tailed) }\end{array}$ & Decision \\
\hline $\begin{array}{l}\text { Organizational commitment } \\
\text { above Quality of Work Life }\end{array}$ & 109 & .886 & .412 & $\begin{array}{l}\text { Data normally } \\
\text { distributed }\end{array}$ \\
\hline
\end{tabular}

\section{Linearity Test}

Another requirement for the classical assumption test is linearity test. The linearity test aims to determine whether two variables have a linear or not significant relationship. The results of the linearity test show that $p=.108>.05$, then it can be said that there is a linear relationship between the variables of the quality of work life and organizational commitment. This testing table can be seen in the Table 5 .

Table 5. ANOVA Test between Quality of Work Life and Organizational Commitment

\begin{tabular}{|c|c|c|c|c|c|c|c|}
\hline & & & Sum of Squares & $d f$ & Mean Square & $F$ & Sig. \\
\hline Organizational & Between groups & (Combined) & 10143.722 & 45 & 225.416 & 3.346 & .000 \\
\hline Commitment* & & Linearity & 5984.946 & 1 & 5984.946 & 88.833 & .000 \\
\hline $\begin{array}{l}\text { Quality of } \\
\text { Work Life }\end{array}$ & & $\begin{array}{l}\text { Deviation } \\
\text { from linearity }\end{array}$ & 4158.776 & 44 & 94.518 & 1.403 & .108 \\
\hline & $\begin{array}{l}\text { Within groups } \\
\text { Total }\end{array}$ & & $\begin{array}{c}4244.517 \\
14388.239\end{array}$ & $\begin{array}{c}63 \\
108\end{array}$ & 67.373 & & \\
\hline
\end{tabular}

\section{Hypothesis Test}

Correlation between Quality of Work Life and Organizational Commitment

Hypothesis test to prove whether there is an influence QWL on OC analyzed by using simple regression test. The correlation value between the two variables is indicated by the $R$ value of .645, while the influence level of QWL on OC shown by the coefficient of determination ( $R$ Square) which is .416 , or the magnitude of the effect is $41.6 \%$ (moderate effect). The results of other analyses are shown in Table 6.

Table 6. Correlation Coefficient of Quality of Work Life with Organizational Commitment

\begin{tabular}{|c|c|c|c|c|c|}
\hline \multirow{2}{*}{ Model } & \multicolumn{2}{|c|}{ Unstandardized Coefficients } & \multirow{2}{*}{$\frac{\text { Standardized Coefficients }}{\text { Beta }}$} & \multirow{2}{*}{$t$} & \multirow{2}{*}{ Sig. } \\
\hline & $\boldsymbol{B}$ & Std. Error & & & \\
\hline (Constant) & 63.741 & 8.367 & & 7.618 & .000 \\
\hline Quality of Work Life & .543 & .062 & .645 & 8.730 & .000 \\
\hline
\end{tabular}


Table 6 describes the regression equation model between OC and QWL. Thus, the model is $\hat{Y}=63.741+.543 X$. This linear equation illustrates that the consistency value of variable OC is 63.741 and a change of one QWL unit will increase the value of OC by .543 . Then it is definite to say that the level of OC of quality assurance employees can be enhanced by good QWL management.

\section{Pearson's Correlation Test}

Hypothesis test to identify the relationship between six of QWL predictors (appropriate and fair compensation, employee participation, career growth and development, social relevance, work environment, work stress) on OC of the quality assurance team's a state university analyzed by Pearson correlation test. The summary testing table can be seen in the Table 7 .
Table 7 directs us to a conclusion that 5 out of 6 predictors in QWL - namely appropriate and fair compensation, employee participation, career growth and development, social relevance, and work environment - are positively correlated with $\mathrm{OC}$ which each indicator is having a value of $r<.05$ and significant level $(p)$ is positive. Meanwhile, the correlation found in the work stress indicator on employees' OC was known to have a negative relationship at $r<.05$ and $p$ $=-.510$.

The career growth and development indicator place the highest rank as the predictor in QWL ( $p=.612)$, while the last indicator to predict level of employees' OC is work environment. It is simply inferred that to increase OC of the quality assurance team's a state university, the main concern lies on keeping the development of employees' abilities and skills as the top facet.

Table 7. Summary of Pearson's Correlation Test

\begin{tabular}{lcccl}
\hline Indicator & $\begin{array}{c}\text { Standard } \\
\text { Deviation }\end{array}$ & $\begin{array}{c}\text { Pearson } \\
(\boldsymbol{r})\end{array}$ & $\begin{array}{c}\text { Level of } \\
\text { Significant }(\boldsymbol{p})\end{array}$ & $\begin{array}{l}\text { Relationship } \\
\text { Strength Category*** }\end{array}$ \\
\hline Appropriate and fair compensation & 3.29 & .00 & $.558^{*}$ & Strong \\
Employee participation & 2.49 & .00 & $.515^{*}$ & Strong \\
Career growth and development & 2.32 & .00 & $.612^{*}$ & Strong \\
Social relevance & 3.28 & .00 & $.498^{*}$ & Moderate \\
Work environment & 3.15 & .00 & $.422^{*}$ & Moderate \\
Work stress & 2.65 & .00 & $-.510^{*}$ & Strong \\
\hline
\end{tabular}

* Correlation in significant at the .01 level (2-tailed)

** According to Cohen's empirical classification, using the significance level of each QWL indicator on OC

\section{Discussion}

\section{Quality of Work Life on Organizational Commitment}

Based on the presented results in the finding section of the current research, it was shown that quality of work life (QWL) has a significant influence on organizational commitment (OC) simultaneously. These results are consistent with some previous studies in this area. For example, in their research on academic staff in a private university in Nigeria, Osibanjo et al. (2019) show that there is significant and positive relationship between QWL with OC. Or another research, such as that conducted by Tamhir et al. (2019), proves that there is a direct positive influence between QWL and affective commitment. They explained that basically the increase in affective commitment of teachers in Ternate Junior High School, North Maluku Province, must be supported by a good, effective, and efficient quality of work life.
The findings in this study indicate that the good perceptions of a state university quality assurance employees regarding QWL can play an important role in determining their positive work attitude, especially in terms of increasing the level of OC. This is based on the argument that employees who feel that the working conditions are match or meet their expectations will tend to enjoy their work more, so the work they report will be more optimal and individually be able to build positive attitudes in their organization.

Organizations that pay less attention to their employee QWL will find it difficult to find or retain workers who are in accordance with the needs of the organization. In addition, because human resources are an essential factor that affects the effectiveness and efficiency of achieving organizational goals, the organization has a responsibility to maintain QWL of its employees, so that they are willing to provide optimal efforts in carrying out their duties. Therefore, to 
increase the quality assurance employees a state university's OC, the implementation of routine assessments of QWL such as a duty load, physical and social environments in organizations, as well as administrative systems, is something that should be done to provide important updated information related to the level of employee welfare to the organization.

Santosa (2017) provides several suggestions regarding things that need to be done on the QWL so that it has an impact on increasing employee OC, including conditioning employees to have confidence in the organization where they work through work restructuring regarding improvements to work methods or systems, a better reward system, providing opportunities for self-development, creating a comfortable and healthy work environment, and developing a strong work ethic to create a conducive and harmonious QWL.

\section{Predictors of Quality of Work Life Affecting Organizational Commitment}

Based on the presented results in the finding section, it was shown that there is a significant relationship between six of QWL predictors (appropriate and fair compensation, employee participation, career growth and development, social relevance, work environment, work stress) on OC of the quality assurance team's a state university $(r<.05)$. According to Cohen's empirical classification, among the six of QWL predictors, appropriate and fair compensation, employee participation, career growth and development, and job stress indicator, it is known to have a strong relationship strength category. Meanwhile, social relevance and work environment indicators are included in this classification's moderate relationship strength category.

Pearson's correlation test results show that among the six of QWL predictors tested, the growth and development career is the most substantial factor affecting the level of quality assurance team's commitment $(p=.612)$. As found in several previous studies, the research results by Wongkar, Saerang, \& Pandowo (2017) and Batvandi \& Ghazavi (2017) also show that predictors of QWL in the form of development of human capabilities have a significant influence on OC. Their research results indicated that providing opportunities for employees to grow and showing their capabilities and creativity has been found to increase their performance and their dependence on the organization.

As explained by Hasmalawati \& Hasanati (2017) regarding QWL, the main thing that is the focus of QWL is its impact on individuals, which is work is made to build the individuals involved in it to be better, not people can do a better job. This statement indirectly explains that the success of a job is not always related to the organization's success in carrying out their projects, but how to improve and develop abilities and skills of employees during the process of achieving organizational goals into individual successes that are grown for organization's future. Therefore, implementing training by universities and faculties, providing opportunities and support for employees to continue their education levels, and implementing supervision from superiors are known to significantly influence the development of employees' abilities and skills of quality assurance to carry out their duties optimally.

The second indicator of predictors of QWL that affects OC of quality assurance team's a state state university is appropriate and fair compensation. A significant positive relationship between this predictor and the level of OC $(r<$ $.05 ; p=.558$ ) could explain that the better the employees' perception of the appropriate and fair compensation they receive, the higher the level of quality assurance team's commitment to their organization. The strong relationship between the two variables also proves one of Maslow's hierarchies of needs, that the fulfilment of legal employee physiological needs, such as wages that are by the workload and the provision of safety and health insurance, are two forms that employees consider to meet their safety needs while working.

These results also align with Batvandi \& Ghazavi (2017) research which shows a significant and positive relationship between fair and adequate payments with OC. The finding implies that positive working conditions and attitudes will basically be awakened when employees receive good and proper treatment from their organization. When there are still many employees who feel they are not fairly compensated for their work, while they believe that the salary level should be mandated or adjusted to a uniform and consistent payout 
guideline, then the level of employees' commitment may decrease (Parvar, Allameh, \& Ansari, 2013). In another case, when employees of the quality assurance team's a state university feel that their working conditions fulfill their expectations, then they are more likely to enjoy their work and report more significant involvement in their work. As a result, they will also be more likely to display positive attitudes towards their organization, such as their commitment level.

Based on the research findings results described, it is known that employee participation is a predictor of QWL, which also has a positive relationship and is included in the third strongest research predictor category with $\mathrm{OC}(p=.515)$. Research conducted by Butali \& Njoroge (2018) and Gallie, Zhou, Felstead, Green, \& Henseke (2017) showed an influence between employee participation on OC, which is higher employee participation in the decision-making process and involvement in setting organizational plans and goals have a positive impact on employee commitment.

The opportunities provided to disseminate and use self-skills, such as the opportunity to speak out and be involved in decision-making or activity implementation, essentially promote employee cognitive growth through enhanced knowledge transfer between them (Scully, Kirkpatrick, \& Locke, 1995). Furthermore, Parvar et al. (2013) explain that a work environment like this can essentially broaden the knowledge base, leading to a better understanding of how work relates to other organizational practices and a greater ability to solve problems. Hence, these results can be interpreted that allowing quality assurance employees to be involved in decisionmaking, express opinions, and participate in the implementation of activities are important factors that can improve employee positive conditions and attitudes, including the level of employee OC.

The next biggest category of relationship strength between predictors of QWL and OC is work stress indicator ( $p=.510$; strong category). The analysis of hypothesis testing invents that work stress has a negative and direct impact on OC. It means when the perception of employee QWL related to work stress is felt high, then employees' OC level will decrease. Various studies have indeed shown a strong influence between work stress on employee OC in the workplace. Adli, Adli, Saleem, \& Saleem (2021) and Yanner, Bernarto, \& Wuisan (2020) showed an influence between work stress and OC. If employees experience stress and less than ideal working conditions, the level of their positive feelings towards the organization will decrease or there will be an imbalance (El Badawy, Chinta, \& Magdy, 2018).

Although psychologically, in principle, a person will tend to do activities that he thinks are fun to do, but this cannot be covered if he does activities that he does not like or based on compulsion, then the work tends to be ineffective and efficient (Hasmalawati \& Hasanati, 2017). Or in other words, if the work pressure felt by quality assurance is considered high, then the employee's job loyalty condition can decrease, which is the employee does not have a strong sense of belonging to the organization. In the end, the implementation of the employees' primary duties as a quality assurance tends to be done half-heartedly, without integrity and responsibility to achieve quality results.

Therefore, it becomes essential for organizations to create ideal and controlled working conditions. Based on the research results of Bhatti, Bhatti, Akram, Hashim, \& Akram (2016), they offer several ways to reduce work stress among employees and increase organizational commitment, namely providing counsel programs to determine employee stress levels, building beneficial and cooperative relationships with colleagues, build effective and supportive relationships with managers, and negotiate with seniors for realistic deadlines on important projects.

Finally, the smallest relationship strength category of QWL predictors with OC found in work environment indicators. The positive relationship shown from the analysis results on the work environment indicator can be interpreted that the better employees' perceptions of their work environment, the level of employees' OC will increase $(r<.05 ; p=.422)$. A statement from the results of a similar study was also presented by Parvar et al. (2013) and Santosa (2017), that a safe and healthy environment basically affects OC. If an organization provides a safe and healthy environment for its employees, and they feel comfortable with their working conditions in that environment, then the employees' 
commitment to the organization will increase (Parvar et al., 2013).

Based on Santosa's (2017) research, one of the elements that affect employee behavior, including employee commitment to their organization, is the environment of the employees themselves. He further explained that the work environment in question must be seen as a whole, namely the support provided by the organization to employees both internally and externally as well as physically and non-physically. Employee management by providing supportive facilities and infrastructure is expected to facilitate quality assurance team members in managing their work and encouraging them to innovate and be creative. Besides, to create a conducive work environment and work climate, creating a fair system and flexible structure is an essential factor in increasing employee loyalty to the organization. These can be in the form of a clear and human division of duties, authorities, and responsibilities, with due regard to employee's ability and their efforts to achieve their career goals.

\section{CONCLUSION}

The results of this study lead us to the conclusion that the quality of work life (QWL) has an influence on the level of organizational commitment (OC) of the quality assurance team's a state university. Or in other words, the level of OC of quality assurance employees can be improved by good quality management of work life.

Further supporting results are the factors that influence OC. The results of the Pearson's correlation test show that there is a significant relationship between six predictors of QWL (appropriate and fair compensation, employee participation, career growth and development, social relevance, work environment, work stress) and OC. It means that these six predictors of QWL have an important role in influencing the level of OC of the quality assurance team of a state university.

In general, because human resources are an essential factor that affects the effectiveness and efficiency of achieving the goals of quality assurance organization, the University has the responsibility to maintain its employee QWL, so they are willing to provide optimal efforts. Based on the research results, it can be said that the predictors of QWL used in this study can be taken into consideration by university as important factors that need to be considered for their quality to build positive perceptions of employees towards their work life, so it is can also develop employee attitudes and conditions positive working.

In simple terms, the study results can also describe some of the efforts that a state university can make in increasing the quality assurance employee's OC based on the importance level of the implementation, namely: 1) There is organizational consistency in providing opportunities for employees to grow and show their capabilities and creativity; 2) Paying wages by the workload and providing occupational safety and health insurance; 3) Provide more expansive opportunities for quality assurance employees to be involved in decision making, express opinions, and participate in the implementation of activities at the faculty and university level; 4) The division of duties and responsibilities is clear and in accordance with the ability of quality assurance employees as an alternative in helping or reducing employee work stress; 5) Build a sense of kinship, free from prejudice, no stratification in the organization, and interpersonal openness between superiors and subordinates or vice versa; 6) Provide a safe and healthy environment for quality assurance employees by procuring a transparent, fair, and precise system and providing facilities and infrastructure to support quality assurance team members in managing their work.

The researcher realizes that the objectivity level in the researcher's findings has several things that are influenced by other factors such as length of employee work at the university as well as quality assurance, gender, and busyness in teaching activities as a lecturer. Researchers know that based on several previous studies, these factors can be known to affect the level of OC as well. Therefore, the researcher attempted to carefully control for the effect of untested independent variables and interpret the findings objectively.

\section{REFERENCES}

Adli, M., Adli, H., Saleem, A., \& Saleem, T. (2021). Job stress among immigrants. International Journal of Innovative Science, Engineering \& Technology, 
8(2), 1-6. https://doi.org/10.13140/ RG.2.2.33481.67680.

Batvandi, Z., \& Ghazavi, M. (2017). The study of the quality of working life with organizational commitment and job satisfaction among the employees using correlation analysis (Case study: Aseman carton making factory of Isfahan). European Online Journal of Natural and Social Sciences, 6(1), 100-110. https:// european-science.com/eojnss/article/ view/4902.

Beloor, V., Nanjundeswaraswamy, T. S., \& Swamy, D. R. (2017). Employee commitment and quality of work life A literature review. The International Journal of Indian Psychology, 4(2), 175188. https://ijip.in/articles/employeecommitment-and-quality-of-work-life-aliterature-review/.

Bhatti, M. H., Bhatti, M. H., Akram, M. U., Hashim, M., \& Akram, Z. (2016). Relationship between job stress and organizational commitment: An empirical study of banking sector. E3 Journal of Business Management and Economics, 7(1), 029-037. https://doi.org/10.18685/ EJBME(7)1 EJBME-15-013.

Butali, P., \& Njoroge, D. (2018). Effect of employee participation on organizational performance with organizational commitment as a moderator. International Journal of Scientific Research and Management, 6(06), 478-485. https://doi. org/10.18535/ijsrm/v6i6.el015.

Cohen, A. (2011). Values and psychological contracts in their relationship to commitment in the workplace. Career Development International, 16(7), 646-667. https://doi. org/10.1108/13620431111187272.

Colquitt, J. A., Lepine, J. A., \& Wesson, M. J. (2015). Organizational behavior: Improving performance and commitment in the workplace. New York, NY: McGraw-Hill Education.

Darmadi, H. (2019). Pengantar pendidikan era globalisasi: Konsep dasar, teori, strategi dan implementasi dalam pendidikan globalisasi. [Introduction to globalization era education: Basic concepts, theory, strategy and implementation in globalization education]. Jakarta, Indonesia: An1mage. https://books. google.co.id/books?id=mICSDwAAQBA $\underline{\mathrm{J} \& \text { printsec }}=$ frontcover $\& \mathrm{hl}=\mathrm{id} \# \mathrm{v}=$ onepag $\underline{\mathrm{e} \& \mathrm{q} \& \mathrm{f}=\text { false. }}$.

Daud, N. (2010). Investigating the relationship between quality of work life and organizational commitment amongst employees in Malaysian firms. International Journal of Business and Management, 5(10), 75-82. https://doi. org/10.5539/ijbm.v5n10p75.

Divaris, K., Vann, W. F., Baker, A. D., \& Lee, J. Y. (2012). Examining the accuracy of caregivers' assessments of young children's oral health status. The Journal of the American Dental Association, 143(11), 1237-1247. https://doi. org/10.14219/jada.archive.2012.0071.

El Badawy, T. A., Chinta, R., \& Magdy, M. M. (2018). Does 'gender' mediate or moderate the relationship between 'quality of work life' and 'organizational commitment'?: Evidence from SMEs in Egypt. Gender in Management, 33(4), 332-348. https://doi. org/10.1108/GM-04-2017-0050.

Gallie, D., Zhou, Y., Felstead, A., Green, F., \& Henseke, G. (2017). The implications of direct participation for organisational commitment, job satisfaction and affective psychological well-being: a longitudinal analysis. Industrial Relations Journal, 48(2), 174-191. https://doi.org/10.1111/ irj.12174.

Geisler, M., Berthelsen, H., \& Muhonen, T. (2019). Retaining social workers: The role of quality of work and psychosocial safety climate for work engagement, job satisfaction, and organizational commitment. Human Service Organizations: Management, Leadership \& Governance, 43(1), 1-15. https://doi.or $\mathrm{g} / 10.1080 / 23303131.2019 .1569574$. 
Ghoniyah, N., \& Masurip. (2011). Peningkatan kinerja karyawan melalui kepemimpinan, lingkungan kerja dan komitmen. [Improving employee performance through leadership, work environment and commitment]. Jurnal Dinamika Manajemen, 2(2), 118-129. https:// journal.unnes.ac.id/nju/index.php/jdm/ article/view/2476.

Gibson, J. L., Ivancevich, J. M., Donnelly, J. H., \& Konopaske, R. (2012). Organizations: Behavior, structure, processes $\left(14^{\text {th }}\right.$ ed). New York, NY: McGraw-Hill.

Greenberg, J. (2010). Managing behavior in organizations $\left(5^{\text {th }}\right.$ ed). Upper Saddle River, NJ: Pearson.

Hasmalawati, N., \& Hasanati, N. (2017). Pengaruh kualitas kehidupan kerja dan motivasi kerja terhadap kinerja karyawan. [The influence of the quality of work life and work motivation on employee performance]. Mediapsi, 3(2), 1-9. https:// doi.org/10.21776/ub.mps.2017.003.02.1.

Holsblat, R. (2014). The relationship between commitment to the organization, perceived organizational support, job satisfaction, and organizational citizenship behavior of teachers. American Journal of Educational Research, 2(12), 1175-1181. https://doi. org/10.12691/education-2-12-7.

Jabbour, C. J. C., \& Santos, F. C. A. (2008). The central role of human resource management in the search for sustainable organizations. The International Journal of Human Resource Management, 19(12), 2133-2154. https://doi. org/10.1080/09585190802479389.

Jie, C., Mansor, N. N. A., \& Kelana, B. W. Y. (2020a). The relationship between professional competencies, job satisfaction and job performance among university counselors in China: A conceptual paper. International Journal of Psychosocial Rehabilitation, 24(5), 1051-1056. https:// doi.org/10.37200/IJPR/V24I5/PR201779.

Jie, C., Mansor, N. N. A., \& Kelana, B. W. Y. (2020b). The effect of professional competencies on job performance: A literature review. International Journal of Psychosocial Rehabilitation, 24(03), 1643-1651. https://doi.org/10.37200/ IJPR/V24I3/PR200912.

Kardoyo. (2011). Analisis penjaminan mutu fakultas ekonomi: Pencapaian sasaran mutu akademik dan kesesuaian prosedur akademik dengan standar mutu Iso 9001:2008. [Economic faculty quality assurance analysis: Achievement of academic quality objectives and conformity of academic procedures with Iso 9001: 2008 quality standards]. Jurnal Pendidikan Ekonomi Dinamika Pendidikan, 6(2), 108-118. https:// journal.unnes.ac.id/nju/index.php/DP/ article/view/5106.

Kartika, L. N., \& Sugiarto, A. (2016). Pengaruh tingkat kompetensi terhadap kinerja pegawai administrasi perkantoran. [The influence of the level of competence on the performance of office administration employees]. Jurnal Ekonomi dan Bisnis, 17(1), 73-90. https://doi.org/10.24914/ jeb.v17i1.240.

Meyer, J. P., \& Herscovitch, L. (2001). Commitment in the workplace: Toward a general model. Human Resource Management Review, 11(3), 299$326 . \quad$ https://doi.org/10.1016/S10534822(00)00053-X.

Osibanjo, O. A., Oyewunmi, A. E., Abiodun, A. J., \& Oyewunmi, O. A. (2019). Quality of work-life and organizational commitment among academics in tertiary education. International Journal of Mechanical Engineering and Technology, 10(2), 418430. https://iaeme.com/Home/article_id/ IJMET $10 \quad 02 \quad 044$.

Parvar, M. R. F., Allameh, S. M., \& Ansari, R. (2013). Effect of quality of work life on organizational commitment by SEM (Case Study: OICO Company). International Journal of Academic Research in Business and Social Sciences, 3(10), 135-144. https://doi.org/10.6007/IJARBSS/v3i10/285. 
Robbins, S. P., \& Judge, T. A. (2013). Organizational behavior. Boston, MA: Pearson Education.

Rogelberg, S. G. (2007). Encyclopedia of industrial and organizational psychology (Vol 2). Thousand Oaks, CA: SAGE Publications.

Santosa, H. (2017). Perceived organizational support, karakteristik tim, quality of work life dan komitmen organisasi: Studi pada pegawai Universitas Negeri Jakarta. [Perceived organizational support, team characteristics, quality of work life and organizational commitment: Studies on employees of the Jakarta State University]. Jurnal Pendidikan Ekonomi dan Bisnis, 4(1), 48-64. https://doi.org/10.21009/ JPEB.004.1.4.

Scully, J. A., Kirkpatrick, S. A., \& Locke, E. A. (1995). Locus of knowledge as a determinant of the effects of participation on performance, affect, and perceptions. Organizational Behavior and Human Decision Processes, 61(3), 276-288. https://doi.org/10.1006/obhd.1995.1022.

Supriyadi, N. Y., \& Sarino, A. (2019). Kunci untuk meningkatkan kinerja. [The key to improving performance]. Jurnal Pendidikan Manajemen Perkantoran, 4(1), 55-66. https://doi.org/10.17509/ jpm.v4i1.14955.

Syukron, B. (2017). Implementasi manajemen mutu terpadu (Studi transformasi pada perguruan tinggi). [Implementation of integrated quality management (study of transformation in higher education)]. Jurnal Pendidikan Ekonomi dan Bisnis, 5(1), 51-62. https://doi.org/10.21009/ JPEB.005.1.4.

Tabassum, L. (2020). Influence of human resource management. International
Journal for Research in Applied Science and Engineering Technology, 8(6), 2491-2494. https://doi.org/10.22214/ ijraset.2020.6401.

Tamhir, L., Sujanto, B., \& Karnati, N. (2019). The effect of job design and quality of work life toward affective commitment of teachers. International Journal of Mechanical Engineering and Technology, 10(3), 1535-1542. https://ssrn.com/ abstract $=3453133$.

Tanriverdi, H., Turan, S., \& Yilmaz, A. (2019). The effect of psychological empowerment on work life quality. In C. Zehir \& E. Erzengin (Eds.). The European Proceedings of Social \& Behavioural Sciences. Turkey: European Publisher, pp. 152-162. https://doi.org/10.15405/ epsbs.2019.12.03.13.

Tnay, E., Othman, A. E. A., Siong, H. C., \& Lim, S. L. O. (2013). The influences of job satisfaction and organizational commitment on turnover intention. Procedia-Social and Behavioral Sciences, 97, 201-208. https://doi.org/10.1016/j. sbspro.2013.10.223.

Wongkar, V. F., Saerang, D. P. E., \& Pandowo, M. H. C. (2017). The effect of quality of work life on organizational commitment (Case study at PT. Bank BRI Branch Manado). Jurnal EMBA: Jurnal Riset Ekonomi, Manajemen, Bisnis dan Akuntansi, 5(3), 4045-4054. https://ejournal.unsrat.ac.id/ index.php/emba/article/view/18290.

Yanner, Y., Bernarto, I., \& Wuisan, D. (2020). The effect of job stress, job satisfaction and organizational commitment on performance. Jurnal Ilmiah Manajemen Bisnis dan Inovasi Universitas Sam Ratulangi, 7(1), 92-102. https://doi.org/ https://doi.org/10.35794/jmbi.v7i1.28388. 